Chemical, Petroleum and Environmental Engineering

\title{
Numerical Simulation of Water Distribution with Uptake Root in Drip Irrigation using Different Soil Hydraulic Models
}

\author{
Israa Saad Faraj * \\ College of Engineering University of \\ Baghdad \\ Iraq-Baghdad \\ nsisraasaad1992@gmail.com
}

\author{
Assist. Prof. Dr. Maysoon Basheer Abid \\ College of Engineering \\ University of Baghdad \\ Iraq-Baghdad \\ dr.maysoonbasheer@gmail.com
}

\begin{abstract}
Surface drip irrigation is one of the most conservative irrigation techniques that help control providing water directly on the soil through the emitters. It can supply fertilizer and providing water directly to plant roots by drippers. One of the essential needs for trickle irrigation nowadays is to obtain more knowledge about the moisture pattern under the trickling source for various types of soil with various discharge levels with trickle irrigation. Simulation numerical using HYDRUS-2D software, version 2.04 was used to estimate an equation for the wetted area from a single surface drip irrigation in unsaturated soil is taking into account water uptake by roots. In this paper, using two soil types were used, namely sandy loam and clay loam, with three types of plants; (corn, tomato, and sweet sorghum). The soil wetting pattern was analyzed each half an hour for three hours of irrigation time and three initial soil moisture content. Equations for wetted radius and wetted depth were predicted and evaluated by utilizing the statistical parameters for the different hydraulic soil models (Model Efficiency (EF) and Root Mean Squares Error (RMSE)). The values RMSE does not exceed $0.40 \mathrm{~cm}$, and EF is greater than 0.96 for all types of soil. These values were between the values obtained from program HYDRUS-2D and the values obtained from formulas. This shows that evolved formula can be utilized to describe the soil wetting pattern from the surface drip irrigation system. The relative error for the different hydraulic soil models was calculated and compared with Brooks and Corey's model, 1964. There was good agreement compared with different models. RMSE was $0.23 \mathrm{~cm}$, while the relative error $-1 \%$ and 1 for $\mathrm{EF}$ for wetted radius.
\end{abstract}

Keywords: HYDRUS-2D, root water uptake, surface drip irrigation, simulation model, soil moisture, wetting pattern.

\footnotetext{
*Corresponding author
}

Peer review under the responsibility of University of Baghdad.

https://doi.org/10.31026/j.eng.2021.04.04

2520-3339 () 2019 University of Baghdad. Production and hosting by Journal of Engineering.

This is an open access article under the CC BY4 license http://creativecommons.org/licenses/by /4.0/).

Article received: $19 / 10 / 2020$

Article accepted: 8/12/2020

Article published:1/4/2021 


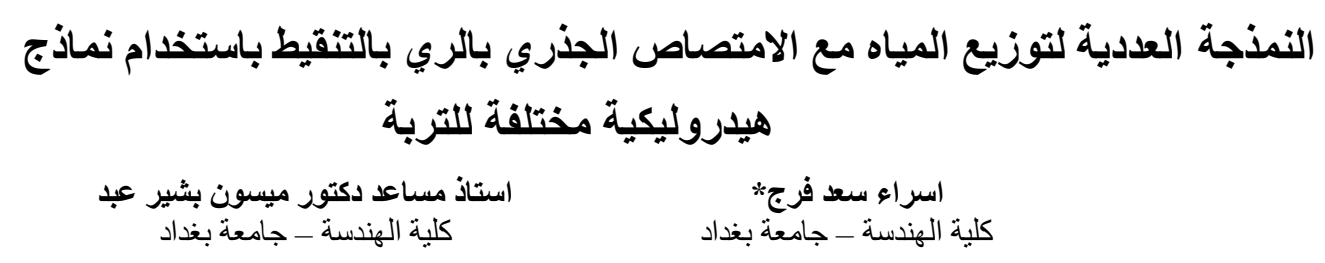

\section{الخلاصة}

يعتبر الري بالتنقيط السطحي هو احد تقنيات الري الحديثة التي ساعدت في السيطرة على تجهيز المباه من خلال توفير المياه

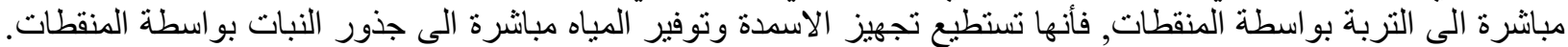

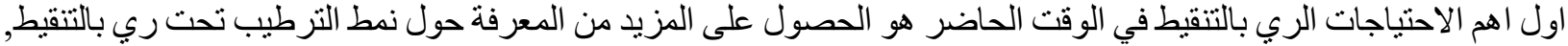
لانو اع مختلفة من الترب وقيم مختلفة لتصريف المنقطة. تمت النمذجة التمبة العددية باستخدام برنامج

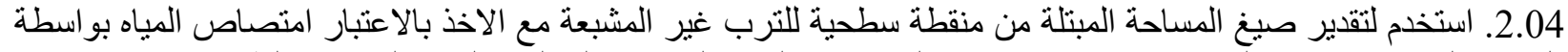

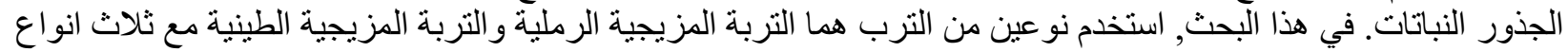

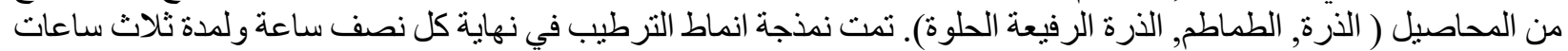

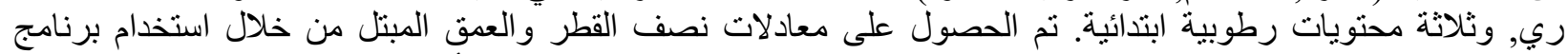

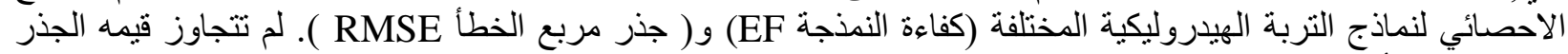

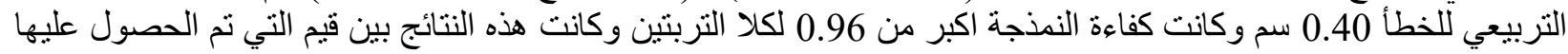
من برنامج ال HYDRUS وبين التي تم الحصول عليها من المعادلات. و هذا يدل على ان المعادلات يمكن استخدامها لوصف نمط الترطيب للتربة من نظام الري بالتنقيط ـ تم حساب الخطأ النسبي لنماذج التربة الهيدروليكية المختلفة وكانت النتائج التي توصل اليها Brooks and Corey, 1964 جيدة مقارنة بالنماذج المختلفة. كان جذر مربع الخطأ 0.23 سم في حين الخطأ النسبي -1\% و 1 لكفاءة النمذجة لنصف القطر المبلل. الكلمات الرئيسية: هايدراس، امتصاص مياه الجذر، ري بالتتقيط السطحي، نموذج محاكاة، المحتوى الرطوبي، انماط الترطيب.

\section{INTRODUCTION}

Drip irrigation is how water is regularly and gradually supplied directly to the plant root region. The concept of this irrigation system is to irrigate only the root zone instead of the entire field surface, thus making the water content of the crop root zone at the optimum level. (Feddes, et al., 1976), showed that simulated water absorption by the roots could be represented by the addition of a volumetric sink term to the soil water continuity equation. This sink term is also expressed due to the difference between the soil and the root soil interface, soil hydraulic conductivity, and some empirical root feature in the pressure head. In this paper, the sink term is considered a function of the soil water content, which varies with the latter depending on the pressure heads generally known to be essential to the roots' water absorption. An implicit model of finite differences was developed and tested with results. Water balance results experimentally obtained in the field the results were comparable. (Prasad R 1988), studied a root water uptake model, which implies a linear variation in the rate of extraction by depth. For model simulation studies, five crops are chosen, and soil moisture depletion is measured for each crop under ideal conditions from various layers. Even comparable calculations are made using the concept of a constant extraction rate. (Ojha and Rai 1996), suggested a new model for soil water absorption by roots. Any of the latest models are found to be particular cases of it. It is found that the suggested model is capable of reflecting different soil moisture uptake patterns observed experimentally. This model's capacity has been investigated using the data of the five crops, namely; (wheat, cabbage, cotton, safflower, and sorghum). Based on several simulations, the frequency of irrigation depends on the type of soil, scheduling parameters. (Vrugt et al. 2001a), developed a two-dimensional root absorption model that can be merged into the numerical multidimensional flow models. The 
two-dimensional absorption model is based on the Raats model (1974) but extended with a radial component. Water content was measured for 16 days at 25 locations. Simulated and measured was contents is a good agreement, with $R^{2}$ value of 0.94 and 0.99 and root mean squares error (RMSE) of $0.015 \mathrm{~m}^{3} \cdot \mathrm{m}^{-3}$. (Vrugt et al., 2001b), tested a three-dimensional root water uptake for the simultaneous, dynamic simulation model of transient soil water flow and uptake root water (around an almond tree). Soil absorption of hydraulic and root water optimized parameters by eliminating residual between the estimated and the calculated simulated water content data. Water content was measured in three-dimensional for 16 days after irrigation. The obtained results showed that water content values during the 16 days, with a root mean square error (RMSE) of 0.018.(Gong et al. 2006), developed a two-dimensional (2D) model of water absorption for single apple trees and validated the model with sap flow and soil water content measurements in an orchard. The calculated data were compared against the transpiration rate outputs and soil water contents from the numerical soil water simulation dynamic that uses the equation of Richards for (2D) water flow and the established root absorption model. The results showed an excellent agreement between the measured data and simulated output. (Yadav and Mathur 2008), developed a nonlinear macroscopic crop water absorption model. A normalized distribution function of root density is used to characterize the relative variability of root density with the root zone's depth and time. The results show that roots can excellent extract water at maximum rates from near root dense surface layers. (Shankar, V., et al. 2012), developed root water uptake for the nonlinear parameter in the (O-R a nonlinear root water uptake model (referred to hereafter as the O-R model)), moisture absorption model from easily calculated plant physiological parameters, such as maximum daily transpiration (Tjmax), maximum root depth (Zrmax), and time to attain the maximum transpiration (t). Data to assess the relationship obtained by reducing the moisture differences found between the field literature recorded depletions of 28 crops and Richards equation based numerically simulated depletion of soil moisture is combined with the moisture uptake configuration of root water uptake. In addition to field experiments on three Indian crops (maize, Indian mustard, and wheat) are conducted to further confirmation of the proposed empirical relationship. Comparing model predictions with field soil observations and moisture depletion in different root regions' layers show good agreement during different stages of plant growth. The obtained results were highlighting the utility of the developed equation for modeling root water uptake over a wide range of crops. (Abid, M. B., 2015), simulated the nonlinear equation of Richards, which describes the transient (2D) water infiltration through unsaturated porous media using the fully implicit and explicit method, the finite volume is predicted numerically. The agreement between the results of the numerical simulation and experimental data is good. (Abid, M. B., 2018), developed a describing spatial distribution of the water content in the unsaturated soil obtained from the Richards equation's numerical solution. Different models are (linear, nonlinear, and exponential root water extraction models) were used in this simulation. A good agreement was obtained when comparing the wetting front advance's predicted results with the published empirical relationship's values. (Khalil and Abid, 2019), simulated soil wetting pattern around a drip surface irrigation of water application depended primarily on hydraulic soil properties, discharge of drip, time of durations, and root water uptake. (Abid, H.N., and Abid, M.B., 2019), predicted soil wetting pattern from one subsurface drip irrigation was analyzed to calculate roots of different plants (pepper, cucumber, and tomato), and there are three soil types, loamy sand, loam, and sandy loam soil, by utilizing the HYDRUS-2D software. (Peddinti et al., 2020), developed reduction functions for root water uptake to simulate plant using linear transpiration under combined water stress and disease stress model, and nonlinear answer. The function established was the introduction in the numerical model HYDRUS-2D to simulate the absorption of water from root 
systems in a root system radially symmetrical flow domain.

This research aims to numerical simulate the water distribution and measure the depths and width of the wetted area using HYDRUS-2D software for specified soil textures. As well as, to study the results of different root water uptake models that estimate the wetted area from a surface emitter, and developing an empirical formula to predict the wetted radius and depth of soils cultivated with plant under trickle irrigation.

\section{GOVERNING EQUATION}

In this study, water movement in the soil was used to numerically model HYDRUS (2D/3D), software version 2.04. The equation of Richards governing water flows from a point source by porous media, variably saturated. This equation can be written in axisymmetric coordinates (Vrugt and Hopmans, 2001; El-Nesr, 2013; and Khalil, 2018):

$$
\frac{\partial \theta}{\partial \mathrm{t}}=\frac{1}{\mathrm{r}} \frac{\partial}{\partial \mathrm{r}}\left[\mathrm{r} \mathrm{K}(\mathrm{H}) \frac{\partial \mathrm{H}}{\partial \mathrm{r}}\right]+\frac{\partial}{\partial \mathrm{z}}\left[\mathrm{K}(\mathrm{H}) \frac{\partial \mathrm{H}}{\partial \mathrm{z}}\right]-\frac{\partial \mathrm{K}(\mathrm{H})}{\partial \mathrm{z}}-\mathrm{S}(\mathrm{H})
$$

where: $\theta=$ is the volumetric soil moisture content $\left(\mathrm{cm}^{3} \cdot \mathrm{cm}^{-3}\right), \mathrm{t}=$ is time $(\mathrm{hr}), \mathrm{H}=$ is soil water pressure head $(\mathrm{cm}), \mathrm{r}=$ is radial (horizontal) coordinate $(\mathrm{cm}), \mathrm{z}=$ is vertical coordinate (upward direction is positive) $(\mathrm{cm}), \mathrm{K}(\mathrm{H})=$ is unsaturated hydraulic conductivity $(\mathrm{cm} / \mathrm{hr}), \mathrm{S}(\mathrm{H})=$ is a sink term that explains the root water uptake expressed as a water volume that removed from a unit volume of soil per unit time $\left(\mathrm{cm}^{3} \cdot \mathrm{cm}^{-3} / \mathrm{hr}\right)$.

\section{HYDRAULIC SOIL MODELS}

HYDRUS comprises the following analytical types to evaluate soil hydraulic properties (Brooks and Corey 1964); (Van Genuchten 1980); (Vogel and Cislerova 1988), and (Kosugi 1996). The soil water retention was modeled using by as:

\subsection{Brooks and Corey (1964):}

$$
\begin{array}{ll}
\mathrm{S}_{\mathrm{e}} & = \begin{cases}|\mathrm{aH}|^{-\mathrm{n}} & \mathrm{H}<-\frac{1}{\mathrm{a}} \\
1 & \mathrm{H} \geq-\frac{1}{\mathrm{a}}\end{cases} \\
\mathrm{K} & =\mathrm{K}_{\mathrm{s}} \mathrm{S}_{\mathrm{e}}^{2 / \mathrm{n}+l+2} \\
\mathrm{~S}_{\mathrm{e}} & =\frac{\theta-\theta_{\mathrm{r}}}{\theta_{\mathrm{s}}-\theta_{\mathrm{r}}}
\end{array}
$$

where : $\mathrm{Se}=$ is effective soil moisture content, dimensionless, $\theta \mathrm{r}=\mathrm{is}$ residual soil moisture content, $\left(\mathrm{cm}^{3} \mathrm{~cm}^{-3}\right), \theta \mathrm{s}=$ is saturated soil moisture content, $\left.\left(\mathrm{cm}^{3} \mathrm{~cm}^{-3}\right)\right), \mathrm{K}_{\mathrm{s}}=$ is saturated hydraulic conductivity $(\mathrm{cm} / \mathrm{hr}), \mathrm{a}=$ is inverse of the air-entry value, $(1 / \mathrm{cm}), \mathrm{n}=$ is pore size distribution index, dimensionless, and $l=$ is a pore-connectivity parameter assumed to be 2.0 in the original study of (Brooks and Corey, 1964). 
3.2 Van Genuchten, 1980; and Mualem (1976):

$$
\begin{array}{ll}
\theta(H)= \begin{cases}\theta_{\mathrm{r}}+\frac{\theta_{\mathrm{s}}-\theta_{\mathrm{r}}}{\left[1+|\mathrm{aH}|^{\mathrm{n}}\right]^{\mathrm{m}}} & \mathrm{H}<0 \\
\theta_{\mathrm{s}} & \mathrm{H} \geq 0\end{cases} \\
\mathrm{m}=1-1 / \mathrm{n}, \quad \mathrm{n}>1
\end{array}
$$

The hydraulic conductivity was believed to be described using the closed-form equation of van Genuchten, 1980, which combines the analytical expression of Eq. (6) with the pore size distribution model of Mualem, 1976:

$\mathrm{K}(\mathrm{H})=\mathrm{K}_{\mathrm{s}} \mathrm{S}_{\mathrm{e}}^{\mathrm{l}}\left[1-\left(1-\mathrm{S}_{\mathrm{e}}^{\frac{1}{\mathrm{~m}}}\right)^{\mathrm{m}}\right]^{2}$

where $l=$ is the pore connectivity parameter 1 in the hydraulic conductivity function was estimated (Mualem, 1976) to be about 0.5 as an average for many soils.

\subsection{Vogel and Císlerová (1988):}

$$
\begin{aligned}
& \theta(H)= \begin{cases}\theta_{\mathrm{r}}+\frac{\theta_{\mathrm{s}}-\theta_{\mathrm{r}}}{\left[1+|\mathrm{a} H|^{\mathrm{n}}\right]^{\wedge} \mathrm{m}} & \mathrm{H}<\mathrm{H}_{\mathrm{s}} \\
\theta_{\mathrm{s}} & \mathrm{H} \geq \mathrm{H}_{\mathrm{s}}\end{cases} \\
& K(H)=\left\{\begin{array}{cc}
\mathrm{k}_{\mathrm{s}} \mathrm{k}_{\mathrm{r}} & \mathrm{H} \leq \mathrm{H}_{\mathrm{s}} \\
\mathrm{k}_{\mathrm{s}}+\frac{\left(\mathrm{H}-\mathrm{H}_{\mathrm{s}}\right)\left(\mathrm{k}_{\mathrm{s}-} \mathrm{k}_{\mathrm{s}}\right)}{\mathrm{H}_{\mathrm{s}-\mathrm{H}_{\mathrm{k}}}} & \mathrm{H}_{\mathrm{k}}<\mathrm{H}<\mathrm{H}_{\mathrm{s}} \\
\mathrm{k}_{\mathrm{s}} & \mathrm{H} \geq \mathrm{H}_{\mathrm{s}}
\end{array}\right. \\
& \mathrm{K}_{\mathrm{r}}=\frac{\mathrm{K}_{\mathrm{s}}}{\mathrm{K}_{\mathrm{s}}}\left(\frac{\mathrm{S}_{\mathrm{e}}}{\mathrm{S}_{\mathrm{es}}}\right)^{\frac{1}{2}}\left[\frac{\mathrm{F}\left(\theta_{\mathrm{r}}\right)-\mathrm{F}(\theta)}{\mathrm{F}\left(\theta_{\mathrm{r}}\right)-\mathrm{F}\left(\theta_{\mathrm{k}}\right)}\right]^{2} \\
& F(\theta)=\left[1-\left(\frac{\theta-\theta_{\mathrm{r}}}{\theta_{\mathrm{s}}-\theta_{\mathrm{r}}}\right)^{\frac{1}{\mathrm{~m}}}\right]^{\mathrm{m}} \\
& \mathrm{S}_{\mathrm{es}}=\frac{\theta_{\mathrm{s}}-\theta_{\mathrm{r}}}{\theta_{\mathrm{s}}-\theta_{\mathrm{r}}}
\end{aligned}
$$




\subsection{Kosugi (1996):}

$$
\mathrm{S}_{\mathrm{e}}=\frac{\theta_{-} \theta_{\mathrm{r}}}{\theta_{\mathrm{s}}-\theta_{\mathrm{r}}}= \begin{cases}\frac{1}{2} \operatorname{erfc}\left\{\frac{\ln \left(\frac{\mathrm{H}}{\mathrm{a}}\right)}{\sqrt{2 \mathrm{n}}}\right\} & (\mathrm{H}<0) \\ 1 & (\mathrm{H} \geq 0)\end{cases}
$$

Application of Mualems model of distribution by pore size (Mualem, 1976) now leads to the following hydraulic conductivity function:

$$
K= \begin{cases}K_{S} S^{\frac{1}{2}}\left\{\frac{1}{2} \operatorname{erfc}\left[\frac{\ln \left(\frac{H}{a}\right)}{\sqrt{2 n}}+\frac{n}{\sqrt{2}}\right]\right\}^{2} & (H<0) \\ K_{S} & (H \geq 0)\end{cases}
$$

\section{THE SINK TERM}

Water absorption by crop roots sinks term in equation (1) that explains the root water uptake expressed as a water volume that is removed from a unit volume of soil per unit time. The sink term S (H) was computed using the Feddes model (Feddes et al., 1978) adapted for a radially symmetric problem (El-Nesr et al., 2013):

$$
\begin{aligned}
& \mathrm{S}(\mathrm{H})=\alpha(H) S_{\mathrm{p}} \\
& \mathrm{S}_{\mathrm{p}}=\beta(\mathrm{z}) \mathrm{T}_{\mathrm{P}} \mathrm{A}_{T} \\
& \beta(\mathrm{z})=\left[\left(1-\frac{\mathrm{z}}{\mathrm{z}_{\mathrm{m}}}\right)\right] \mathrm{e}^{-}\left(\frac{\mathrm{P}_{\mathrm{z}}}{\mathrm{z}_{\mathrm{m}}}\left|\mathrm{z}^{*}-\mathrm{z}\right|\right)
\end{aligned}
$$

where: $\mathrm{S}(\mathrm{H})=$ is a sink term that explains the root water uptake expressed as a water volume that removed from a unit volume of soil per unit time, $\left(\mathrm{cm}^{3} \mathrm{~cm}^{-3} / \mathrm{hr}\right), \mathrm{Sp}=$ is a potential root water uptake rate, $\left(\mathrm{cm}^{3} \mathrm{~cm}^{-3} / \mathrm{hr}\right), \alpha(\mathrm{H})=$ is a dimensionless water stress response function of the soil water pressure head varies between 0 and 1, (Feddes, et al., 1978), as shown in Fig. 1, $\beta(z)=$ is A function for describing the spatial root distribution, (Vrugt, et al., 2001), $(-), \mathrm{zm}=$ is the maximum rooting lengths in the $\mathrm{z}$-direction, $(\mathrm{cm}), \mathrm{rm}=$ the maximum rooting raduis in the $\mathrm{r}$ direction, $(\mathrm{cm}), \mathrm{z}=$ is distances from the origin of the plant in the $\mathrm{z}$-direction, $(\mathrm{cm}),, \mathrm{pz}=\mathrm{is}$ empirical parameters, $(-), \mathrm{z}^{*}=$ is empirical parameters, $(\mathrm{cm}), \mathrm{Tp}=$ is the potential transpiration rate, $(\mathrm{cm} / \mathrm{hr})$, and $\mathrm{A}_{\mathrm{T}}=$ is the surface area associated with the transpiration process,.$\left(\mathrm{cm}^{2}\right)$.

$$
\mathrm{A}_{\mathrm{T}}=\pi\left(\mathrm{r}_{\mathrm{e}} * \% \mathrm{P}_{\mathrm{s}}\right)^{2}
$$

where $r_{e}=$ radius of infiltration surface area, $(\mathrm{cm}), \mathrm{P}_{\mathrm{s}}=$ the percentage of wetting was considered to be equal to $40 \%$.

Table 1 shows the parameters describing a spatial root distribution for the HYDRUS model Vrugt, 2001. 


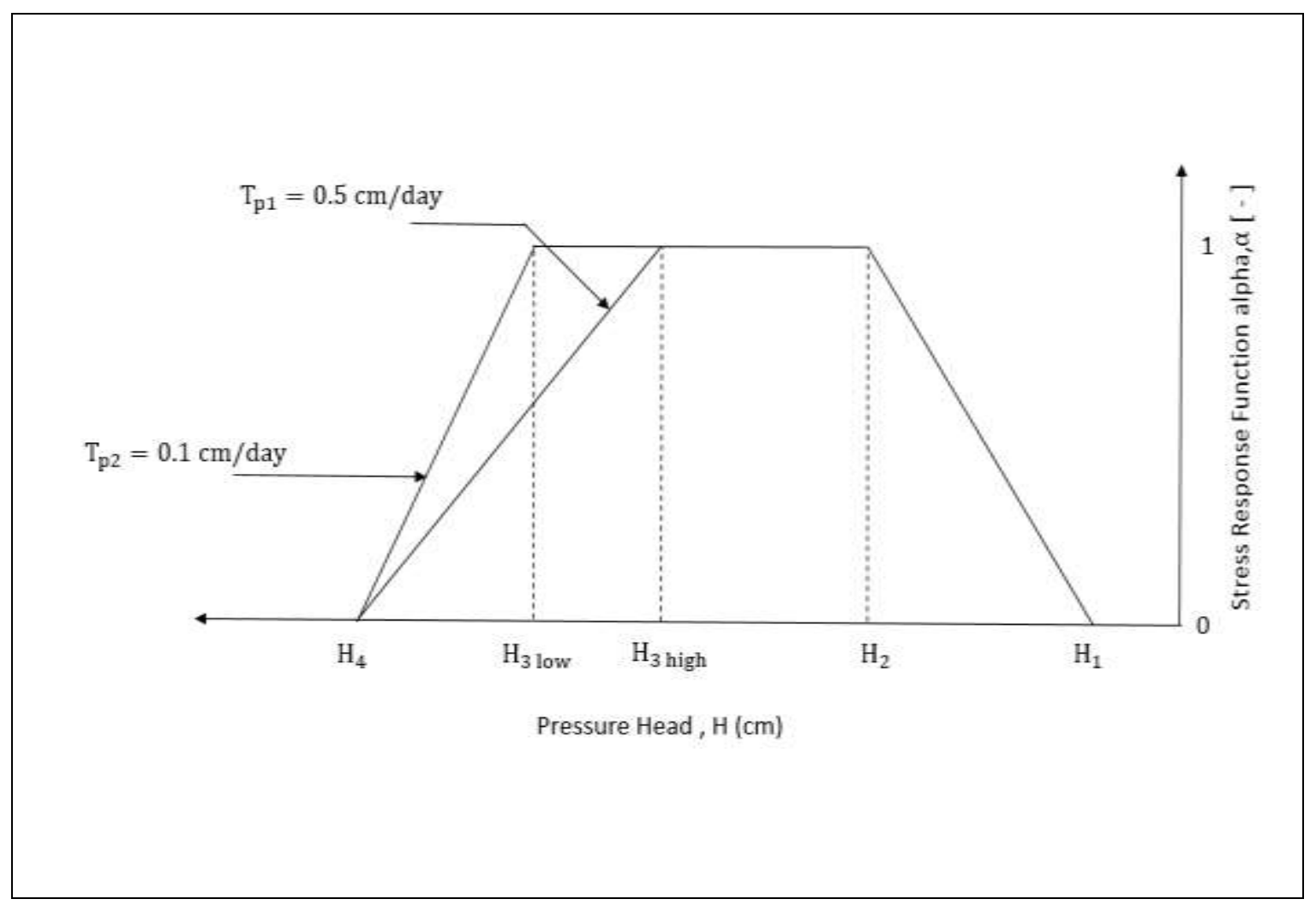

Figure 1. Schematic of the sink-term variable alpha as a function of the soil water pressure head.

Table 1. Parameter definition a spatial root distribution for HYDRUS model.

\begin{tabular}{|l|c|c|c|c|c|}
\hline Crop type & $\mathbf{Z}_{\mathbf{m}}$ & $\mathbf{Z}^{*}$ & $\mathbf{Z}$ & $\mathbf{P}_{\mathbf{z}}$ & $\boldsymbol{\beta}(\mathbf{z})$ \\
& $(\mathbf{c m})$ & $(-)$ & $(\mathbf{c m})$ & $(-)$ & $(-)$ \\
\hline *Corn & 30 & 1 & 20 & 1 & 0.18 \\
\hline *Tomato & 25 & 1 & 10 & 1 & 0.42 \\
\hline **Sweet & 65 & 10 & 20 & 1 & 0.59 \\
\hline
\end{tabular}

* Taken from Khalil, L. A., (2018). ** Taken from Ramos et al., (2012).

HYDRUS software uses Galerkin's finite- element method The hydraulic parameters $\left(K_{s}, \theta_{\mathrm{s}}, \theta_{\mathrm{r}}\right.$, $\mathrm{a}, \mathrm{n})$, initial soil moisture content, and root distribution parameters $\left(\mathrm{r}_{\mathrm{m}}, \mathrm{Z}_{\mathrm{m}}, \mathrm{P}_{\mathrm{r}}, \mathrm{P}_{\mathrm{z}}, \mathrm{r}^{*}, \mathrm{z}^{*}\right)$ Were required to run the model. Wetting patterns from a surface drip irrigation were predicted by Utilizing two different soil textures, namely sandy loam and clay loam Soil. The characteristics of these soil were shown in Table 2. 


\section{INITIAL AND BOUNDARY CONDITIONS}

Since water flows from a surface drip were two-dimensional axisymmetric, half the domains required to be simulated in HYDRUS-2D. The single surface trickle was placed at the left top corner of the domain near to crop root, as shown in Fig. 2. The dimension horizontal simulated of the wetting design represents the wetted radius. In this paper, were domain to be $60 \mathrm{~cm}$ in width and $80 \mathrm{~cm}$ in depth. The top surface area, the flow boundary, was assumed to be zero along the drip irrigation boundary, where a constant flow was considered to the drip. The sides (right and left) were assumed to be zero, and the bottom to be a free drainage boundary. The radius of assuming unit flow rate area equal to the hydraulic conductivity of the saturated soil when the pressure head was assumed to be zero (Naglič, et al., 2014):

$$
\mathrm{q}_{\mathrm{f}}=\frac{\mathrm{Q}}{\mathrm{A}}=\mathrm{K}_{\mathrm{s}}
$$

where $\mathrm{Q}=$ Flow rate of the emitter, $(\mathrm{l} / \mathrm{hr}), \mathrm{A}=$ Saturated surface area $=\pi \mathrm{r}^{\wedge} 2,\left(\mathrm{~cm}^{2}\right)$ and $\mathrm{qf}=$ Flux per unit area, $(\mathrm{cm} / \mathrm{hr})$.

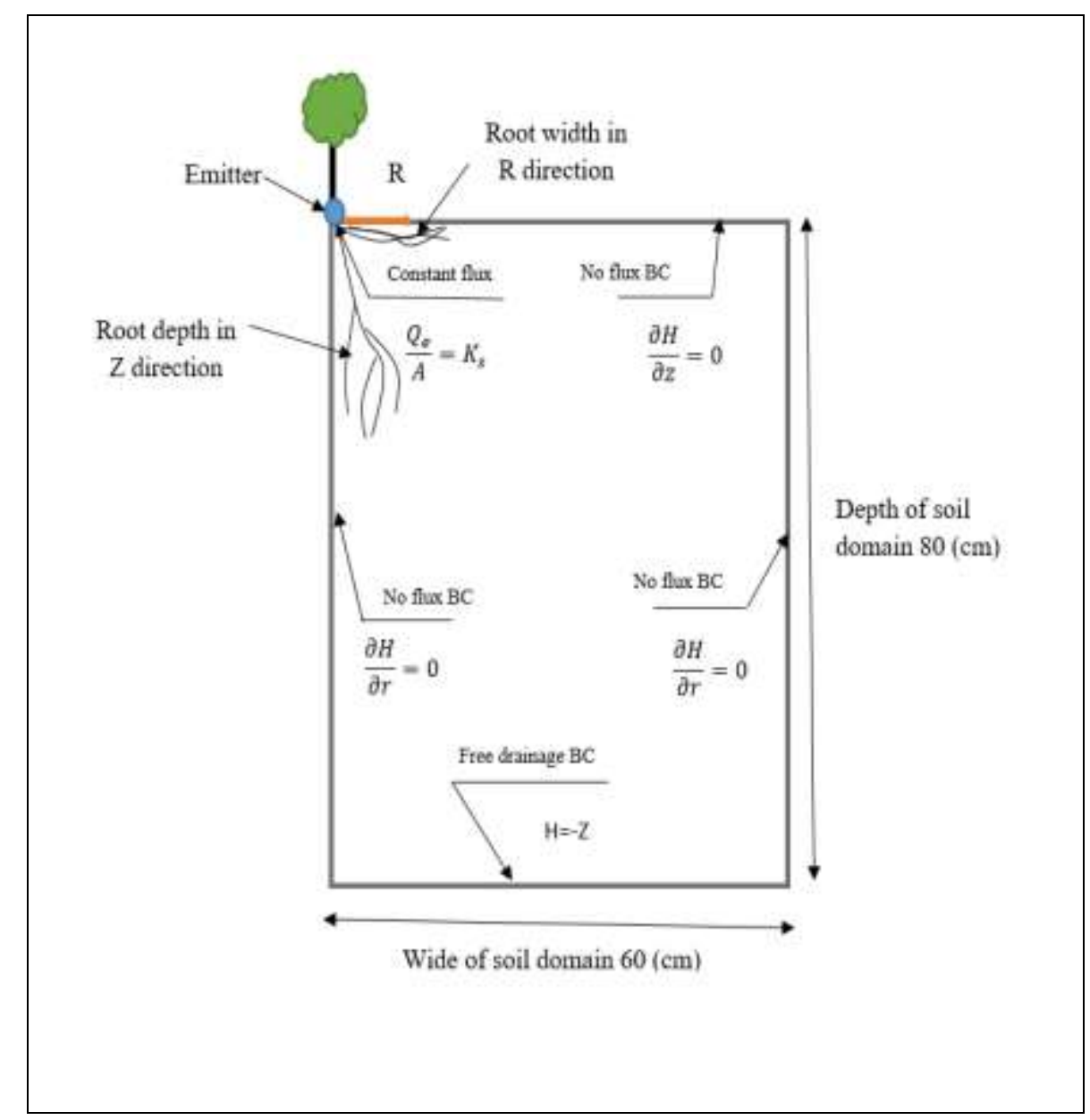

Figure. 2. Schematic representation of the boundary conditions utilized in all simulations. 
Table 2. Physical properties of soils considered in HYDRUS-2D software for different models soil textured

\begin{tabular}{|c|c|c|c|c|c|c|}
\hline $\begin{array}{c}\text { Soil hydraulic } \\
\text { models }\end{array}$ & Soil type & $\begin{array}{c}\text { Ks } \\
(\mathrm{cm} / \mathrm{hr})\end{array}$ & $\begin{array}{c}\theta_{\mathrm{r}} \\
\left(\mathrm{cm}^{3} / \mathrm{cm}^{3}\right)\end{array}$ & $\begin{array}{c}\theta_{\mathrm{s}} \\
\left(\mathrm{cm}^{3} / \mathrm{cm}^{3}\right)\end{array}$ & $\begin{array}{c}\alpha \\
(1 / \mathrm{cm})\end{array}$ & $\mathbf{n}$ \\
\hline \multirow{2}{*}{$\begin{array}{l}\text { Brooks and } \\
\text { Corey, } \\
(1964)\end{array}$} & $\begin{array}{c}\text { Sandy } \\
\text { loam }\end{array}$ & 2.590 & 0.041 & 0.453 & 0.068 & 0.322 \\
\hline & $\begin{array}{l}\text { Clay } \\
\text { loam }\end{array}$ & 0.230 & 0.075 & 0.366 & 0.038 & 0.194 \\
\hline \multirow{4}{*}{$\begin{array}{l}\text { Van } \\
\text { Genuchten, } \\
(1980)\end{array}$} & $\begin{array}{l}* \text { Sandy } \\
\text { loam }\end{array}$ & 1.933 & 0.039 & 0.387 & 0.034 & 1.416 \\
\hline & $\begin{array}{l}* \text { Clay } \\
\text { loam }\end{array}$ & 0.518 & 0.088 & 0.464 & 0.009 & 1.416 \\
\hline & $\begin{array}{c}* * \text { Sandy } \\
\text { loam }\end{array}$ & 1.986 & 0.049 & 0.379 & 0.034 & 1.459 \\
\hline & $\begin{array}{c}* * \text { Clay } \\
\text { loam }\end{array}$ & 0.260 & 0.095 & 0.410 & 0.019 & 1.310 \\
\hline \multirow{2}{*}{$\begin{array}{l}\text { Vogel and } \\
\text { Císlerová, } \\
\text { (1988) }\end{array}$} & $\begin{array}{l}\text { Sandy } \\
\text { loam }\end{array}$ & 4.421 & 0.065 & 0.410 & 0.075 & 1.890 \\
\hline & $\begin{array}{l}\text { Clay } \\
\text { loam }\end{array}$ & 0.260 & 0.095 & 0.410 & 0.019 & 1.310 \\
\hline \multirow[t]{2}{*}{$\begin{array}{l}\text { Kosugi, } \\
\text { (1996) }\end{array}$} & $\begin{array}{l}\text { Sandy } \\
\text { loam }\end{array}$ & 4.421 & 0.065 & 0.410 & 27.423 & 1.260 \\
\hline & $\begin{array}{l}\text { Clay } \\
\text { loam }\end{array}$ & 0.260 & 0.095 & 0.410 & 666.326 & 2.813 \\
\hline
\end{tabular}

(*for corn, and sweet sorghum plant) and (** for tomato plant).

Three initial soil moisture contents were used ranged between field capacity and wilting point for different hydraulic models, as shown in Table 3.

Table 3. Values of the initial soil water content.

\begin{tabular}{|c|c|c|c|c|}
\hline Soil hydraulic model & \multicolumn{1}{|c|}{$\begin{array}{c}\text { Soil } \\
\text { texture }\end{array}$} & \multicolumn{3}{|c|}{$\begin{array}{c}\text { Initial soil moisture content } \\
\left(\mathbf{c m}^{\mathbf{3}} / \mathbf{c m}^{\mathbf{3}}\right)\end{array}$} \\
\hline $\begin{array}{c}\text { Brooks and Corey,(1964); } \\
\text { and Van Genuchten, (1980) }\end{array}$ & Sandy loam & 0.15 & 0.18 & 0.22 \\
\cline { 2 - 5 } & Clay loam & 0.15 & 0.18 & 0.22 \\
\hline $\begin{array}{c}\text { Vogel and Císlerová, (1988); } \\
\text { and Kosugi, (1996) }\end{array}$ & Sandy loam & 0.15 & 0.17 & 0.18 \\
\cline { 2 - 5 } & Clay loam & 0.15 & 0.18 & 0.22 \\
\hline
\end{tabular}




\section{STATISTICAL PARAMETERS}

Statistical parameters were used to test the discrepancy between the results obtained from HYDRUS (2D/3D) software and the results obtained from the developed formulas. These parameters include modeling efficiency (EF), which has the maximum at 1 when the predicted value is excellent match the observed ones (Naglic, 2014), a model with a value EF near 0 would not typically be assumed as a better model. Additionally the root mean square error (RMSE) was applied. The optimal value is zero. The root mean square errors, modeling efficiency, were calculated as follows (Willmott, 1982):

$$
\begin{gathered}
\text { RMSE }=\sqrt{\frac{\sum_{i=1}^{n}\left(M_{i}-S_{i}\right)^{2}}{n}} \\
\text { EF }=1-\frac{\sum_{i=1}^{n}\left(M_{i}-S_{i}\right)^{2}}{\sum_{i=1}^{n}\left(M_{i}-M_{e}\right)^{2}} \\
\text { Error } \%=100\left(\frac{M-S}{M}\right)
\end{gathered}
$$

where: $\mathrm{n}=$ number of values, $\mathrm{M}_{\mathrm{i}}=$ values predicted by using HYDRUS-2D software, $(\mathrm{cm}), \mathrm{S}_{\mathrm{i}}=$ values obtained from the developed formulas, $(\mathrm{cm}), \mathrm{M}_{\mathrm{e}}=$ mean of values obtained from HYDRUS2D software, $(\mathrm{cm}), \mathrm{M}=$ measured wetted, $(\mathrm{cm})$, and $\mathrm{S}=$ simulated wetted, $(\mathrm{cm})$.

\section{RESULTS}

An empirical equation to predict the wetted radius and depth will be obtained for sandy loam and clay loam soils. Similar trials were followed for other soil types and relationships pertinent were developed to predict the wetted radius and depth as shown in Tables (4), and (5) for the soil type used in this research and for different hydraulic soil model (Brooks and Corey (1964); Van Genuchten (1980); Vogel and Císlerová (1988); and Kosugi (1996)). Table (6) show the result values of the statistical parameters for wetted radius and depth by used the plotting, fitting, and expressing pertinent relationships method for the different hydraulic soil models. The values of the RMSE do not exceed $0.40 \mathrm{~cm}$, and EF is greater than 0.96 for all types of soil. These values were between the values obtained from HYDRUS-2D and the values obtained from the formulas in Table (4) and Table (5). These errors show that the formulas could be used to predict the wetted zone in these soil types.

Table 4. Empirical formulas to predict the wetted radius and depth for sandy loam soil by used plotting, fitting, and expressing pertinent relationships.

\begin{tabular}{|c|c|c|c|}
\hline $\begin{array}{c}\text { Soil hydraulic } \\
\text { model }\end{array}$ & $\begin{array}{c}\text { Ks } \\
(\mathbf{c m} / \mathbf{h r})\end{array}$ & $\begin{array}{c}\text { Wetted radius, } \mathbf{r} \\
(\mathbf{c m})\end{array}$ & $\begin{array}{c}\text { Wetted depth, } \mathbf{z} \\
(\mathbf{c m})\end{array}$ \\
\hline $\begin{array}{c}\text { Brooks and Corey, } \\
(1964)\end{array}$ & 2.59 & $\mathrm{r}=25.542 \theta_{\mathrm{i}}^{0.212} \mathrm{Q}^{0.289} \mathrm{t}^{0.239}$ & $\mathrm{z}=26.009 \theta_{\mathrm{i}}^{0.452} \mathrm{Q}^{0.192} \mathrm{t}^{0.498}$ \\
\hline $\begin{array}{c}\text { Van Genuchten, } \\
(1980)\end{array}$ & 1.933 & $\mathrm{r}=28.932 \theta_{\mathrm{i}}^{0.249} \mathrm{Q}^{0.310} \mathrm{t}^{0.223}$ & $\mathrm{z}=30.668 \theta_{\mathrm{i}}^{0.588} \mathrm{Q}^{0.191} \mathrm{t}^{0.538}$ \\
\hline $\begin{array}{c}\text { Vogel and } \\
\text { Císlerová, (1988) }\end{array}$ & 4.421 & $\mathrm{r}=22.276 \theta_{\mathrm{i}}^{0.177} \mathrm{Q}^{0.273} \mathrm{t}^{0.245}$ & $\mathrm{z}=39.899 \theta_{\mathrm{i}}^{0.561} \mathrm{Q}^{0.249} \mathrm{t}^{0.483}$ \\
\hline Kosugi, (1996) & 4.421 & $\mathrm{r}=22.327 \theta_{\mathrm{i}}^{0.179} \mathrm{Q}^{0.274} \mathrm{t}^{0.245}$ & $\mathrm{z}=42.607 \theta_{\mathrm{i}}^{0.598} \mathrm{Q}^{0.256} \mathrm{t}^{0.481}$ \\
\hline
\end{tabular}


Table 5. Empirical formulas to predict the wetted radius and depth for clay loam soil by used plotting, fitting, and expressing pertinent relationships.

\begin{tabular}{|c|c|c|c|}
\hline $\begin{array}{c}\text { Soil hydraulic } \\
\text { model }\end{array}$ & $\begin{array}{c}\text { Ks } \\
(\mathbf{c m} / \mathbf{h r})\end{array}$ & $\begin{array}{c}\text { Wetted radius, } \mathbf{r} \\
(\mathbf{c m})\end{array}$ & $\begin{array}{c}\text { Wetted depth, } \mathbf{z} \\
(\mathbf{c m})\end{array}$ \\
\hline $\begin{array}{c}\text { Brooks and } \\
\text { Corey, (1964) }\end{array}$ & 0.23 & $\mathrm{r}=44.221 \theta_{\mathrm{i}}^{0.063} \mathrm{Q}^{0.457} \mathrm{t}^{0.047}$ & $\mathrm{z}=16.115 \theta_{\mathrm{i}}^{0.875} \mathrm{Q}^{-0.002} \mathrm{t}^{0.682}$ \\
\hline $\begin{array}{c}\text { Van Genuchten } \\
(1980)\end{array}$ & 0.518 & $\mathrm{r}=30.499 \theta_{\mathrm{i}}^{0.058} \mathrm{Q}^{0.423} \mathrm{t}^{0.082}$ & $\mathrm{z}=12.054 \theta_{\mathrm{i}}^{0.559} \mathrm{Q}^{0.004} \mathrm{t}^{0.657}$ \\
\hline $\begin{array}{c}\text { Vogel and } \\
\text { Císlerová, } \\
(1988)\end{array}$ & 0.26 & $\mathrm{r}=38.286 \theta_{\mathrm{i}}^{0.020} \mathrm{Q}^{0.453} \mathrm{t}^{0.039}$ & $\mathrm{z}=5.988 \theta_{\mathrm{i}}^{0.416} \mathrm{Q}^{-0.018} \mathrm{t}^{0.616}$ \\
\hline \begin{tabular}{c} 
Kosugi, (1996) \\
\hline
\end{tabular} & 0.26 & $\mathrm{r}=38.262 \theta_{\mathrm{i}}^{0.020} \mathrm{Q}^{0.453} \mathrm{t}^{0.039}$ & $\mathrm{z}=5.944 \theta_{\mathrm{i}}^{0.417} \mathrm{Q}^{-0.021} \mathrm{t}^{0.619}$ \\
\hline
\end{tabular}

Table 6. The developing formulas obtained statistical parameter values for predicted values, and those were obtained by using HYDRUS-2D software.

\begin{tabular}{|c|c|c|c|c|c|c|}
\hline \multirow[t]{2}{*}{$\begin{array}{l}\text { Soil hydraulic } \\
\text { models }\end{array}$} & \multirow[t]{2}{*}{$\begin{array}{c}\mathbf{K s} \\
(\mathbf{c m} / \mathbf{h r})\end{array}$} & \multirow[t]{2}{*}{ Soil texture } & \multicolumn{2}{|c|}{$\begin{array}{c}\text { Wetted radius, } r \\
(\mathrm{~cm})\end{array}$} & \multicolumn{2}{|c|}{$\begin{array}{l}\text { Wetted depth, } \mathrm{z} \\
\text { (cm) }\end{array}$} \\
\hline & & & $\mathbf{E F}$ & RMSE & EF & RMSE \\
\hline \multirow{2}{*}{$\begin{array}{c}\text { Brooks and Corey, } \\
\text { (1964) }\end{array}$} & 2.59 & Sandy loam & 0.99 & 0.29 & 0.99 & 0.37 \\
\hline & 0.23 & Clay loam & 0.99 & 0.30 & 0.99 & 0.21 \\
\hline \multirow{2}{*}{$\begin{array}{l}\text { Van Genuchten, } \\
\text { (1980) }\end{array}$} & 1.933 & Sandy loam & 0.99 & 0.30 & 0.99 & 0.39 \\
\hline & 0.518 & Clay loam & 0.99 & 0.30 & 0.99 & 0.22 \\
\hline \multirow{2}{*}{$\begin{array}{c}\text { Vogel and } \\
\text { Císlerová, (1988) }\end{array}$} & 4.421 & Sandy loam & 0.99 & 0.12 & 0.99 & 0.23 \\
\hline & 0.26 & Clay loam & 0.99 & 0.24 & 0.96 & 0.26 \\
\hline \multirow[t]{2}{*}{ Kosugi, (1996) } & 4.421 & Sandy loam & 0.99 & 0.12 & 0.99 & 0.29 \\
\hline & 0.26 & Clay loam & 0.99 & 0.24 & 0.96 & 0.27 \\
\hline
\end{tabular}

\section{PERFORMANCE OF THE MODELS}

The models' performance was tested by comparing the predicted wetted radius and depth compared with (Selim, 2013) for sandy loam soil with plant tomato at drip discharge $1.01 \mathrm{l} / \mathrm{hr}$, and initial water content $0.15\left(\mathrm{~cm}^{3} / \mathrm{cm}^{3}\right)$ with time $3.67 \mathrm{hr}$. The relative error values were shown in Tables 7, 8, 9, and 10 for different hydraulic soil models. A good agreement was obtained when comparing the predicted numerical results with Selim's measured values (2013). The relative error was used to the different soil hydraulic models, was results by the model's results are (Brooks and Corey, 1964), in good agreement compared with different models. The RMSE was $0.23 \mathrm{~cm}$, while the relative error $-1 \%$ and $1 \%$ for $\mathrm{EF}$; this results in a wetted radius, but wetted depth were 
RMSE $0.99 \mathrm{~cm}$ and relative error of $4.5 \%$ and $1 \%$ for EF this results for model (Brooks and Corey, 1964).

Table 7. Comparison of wetted radius and wetted depth simulated by HYDRUS -2 D with those simulated by various techniques for (Brook and Corey, 1964).

\begin{tabular}{|l|c|c|c|c|}
\hline HYDRUS & Selim, 2013 & Relative error \% & EF & $\begin{array}{c}\text { RMSE } \\
\text { (cm) }\end{array}$ \\
\hline \multicolumn{2}{|l|}{ Wetted radius r, (cm) } & & 1 & 0.23 \\
\hline 23.23 & 23 & -1 & 1 & 0.99 \\
\hline \multicolumn{2}{|l|}{ Wetted depth z, (cm) } & 4.5 & 1 & \\
\hline 21.01 & 22 &
\end{tabular}

Table 8. Comparison of wetted radius and wetted depth simulated by HYDRUS $-2 \mathrm{D}$ with those simulated by various techniques for (Van Genuchten, 1980).

\begin{tabular}{|c|c|c|c|c|}
\hline HYDRUS & Selim, 2013 & Relative error \% & EF & $\begin{array}{c}\text { RMSE } \\
\text { (cm) }\end{array}$ \\
\hline \multicolumn{2}{|c|}{ Wetted radius r, (cm) } & & & 1.62 \\
\hline 24.62 & 23 & -7.04 & 1 & 0.89 \\
\hline \multicolumn{2}{|c|}{ Wetted depth $\mathbf{z}, \mathbf{c m})$} & 4.05 & 1 & \\
\hline 21.11 & 22 &
\end{tabular}

Table 9. Comparison of wetted radius and wetted depth simulated by HYDRUS -2 D with those simulated by various techniques for (Vogel and Císlerová, 1988).

\begin{tabular}{|c|c|c|c|c|}
\hline HYDRUS & Selim, 2013 & Relative error \% & EF & $\begin{array}{c}\text { RMSE } \\
\text { (cm) }\end{array}$ \\
\hline \multicolumn{2}{|c|}{ Wetted radius r, (cm) } & & & 0.98 \\
\hline 22.02 & 23 & 4.26 & 1 & 3.9 \\
\hline \multicolumn{2}{|c|}{ Wetted depth z, (cm) } & -17.73 & 1 & \\
\hline 25.90 & 22 &
\end{tabular}


Table 10. Comparison of wetted radius and wetted depth simulated by HYDRUS $-2 \mathrm{D}$ with those simulated by various techniques for (Kosugi, 1996).

\begin{tabular}{|c|c|c|c|c|}
\hline HYDRUS & Selim, 2013 & Relative error \% & EF & $\begin{array}{c}\text { RMSE } \\
(\mathbf{c m})\end{array}$ \\
\hline \multicolumn{2}{|c|}{ Wetted radius r, (cm) } & & 1 & 0.97 \\
\hline 22.03 & 23 & 4.22 & 1 & 3.60 \\
\hline \multicolumn{2}{|c|}{ Wetted depth z, (cm) } & -16.27 & 1 & \\
\hline 25.58 & 22 &
\end{tabular}

\section{CONCLUSIONS}

1-Soil wetting pattern from a single surface drip was analyzed, taking into account roots of different plants (corn, tomato, and sweet sorghum) and two soil textures, namely sandy loam and clay loam soil, by utilizing the software HYDRUS-2D, version 2.04.

2- HYDRUS-2D solve Richards's equation of nonlinear water movement in unsaturated soils.

3- Developing equation to predict the wetted pattern. A nonlinear regression analysis supplied by STATISTICA, version 12, was used to develop empirical equations to predict wetted radius and depth for sandy loam and clay loam soils cultivated with crops.

4- STATISTICA program was used to check the difference between expected results from the empirical equation and the results obtained from HYDRUS-2D software.

5- The RMSE does not exceed $0.40 \mathrm{~cm}$, while EF is greater than 0.96 for all types of soil. These values were between the values obtained from program HYDRUS-2D and values obtained from empirical formulas. The developing empirical formulas are general and can be used to design the trickle irrigation system.

6-The estimated wetted radius and depth simulated by the HYDRUS-2D software model wgood agreements with Selim's measured values data (2013).

7-The relative error was used to the different hydraulic soil models, was resulted by the model is (Brook and Corey, 1964), in good agreement compared with different models.

8-The RMSE was $0.23 \mathrm{~cm}$, while the relative error $-1 \%$ and 1 for EF. This results for wetted radius, but wetted depth was RMSE $0.99 \mathrm{~cm}$ and relative error $4.5 \%$ and 1 for EF this results for model (Brook and Corey, 1964). 


\section{REFERENCES}

- Abid, H. N., and Abid, M. B., 2019, Predicting Wetting Patterns in Soil from a Single Subsurface Drip Irrigation System. Journal of Engineering Vol.25, No.9, PP.41-53.

- Abid, M. B., 2015. Numerical Simulation of Two- Dimensional Unsaturated Flow from a Trickle Irrigation Source using the Finite- Volume Method. Journal of Irrigation and Drainage Engineering DOI: 10.1061/(ASCE) IR. 1943-4774.0000813.

- Abid, M. B., 2018. Numerical Simulation of Soil Trickle Irrigation using Different One Dimensional Models of Root water Uptake. International Journal of Civil Engineering and Technology (IJCIET), 9, (9), pp. 2029-2042.

- Brooks, R. H., and Corey, A. T., 1964. Hydraulic Properties of Porous Media. Hydrol. Paper no. 3, Colorad State Univ. Fort Collins, Co, USA.

- El-Nesr, M. N., Alazba, A. A., and Šimunek, J., 2013. HYDRUS Simulations of the Effects of Dual-Drip Subsurface Irrigation and a Physical Barrier on Water Movement and Solute Transport in Soils. Irrig Sci, DOI 10.1007/s00271-013-0417-x.

- Feddes, R. A., Kowalik, P., Kolinska-Malinka, K., and Zaradny, H., 1976. Simulation of Field Water Uptake by Plants using a Soil Water Dependent Root Extraction Function. Journal of Hydrology, Vol. 31, PP.13-26.

- Feddes, R. A., Kowalik, P. J., and Zaradny, H., 1978. Simulation of Field Water Use and Crop Yield. Wiley, New York, NY.

- Gong, D., Kaug, S., Zhang, L., Du, T., and Yao, L., 2006. A Two Dimensional Model of Root Water Uptake for Single Apple Trees and its Verification with Sap Flow and Soil Water Content Measurements. Agriculture Water Management. Vol. 83, PP. 119-129.

- Khalil, L. A., 2018. Numerical Simulation of Unsaturated Soil Water Flow from a Surface Point Source with Plants. M.Sc. thesis, Department of Water Resource Engineering, College of Engineering, University of Baghdad, Baghdad, Iraq.

- Khalil, L. A., and Abid, M. B., 2019. Numerical Simulation of Unsaturated Soil Water from a Trickle Irrigation System for Sandy Loam Soils. Journal of Engineering Vol.25, No.3, PP.38-52.

- Kosugi, K., 1996. Lognormal Distribution Model for Unsaturated Soil Hydraulic Properties. Water Resour.Res., Vol.32, No. 9, PP. 2697-2703.

- Mualem, Y., 1976, A New Model for Predicting the Hydraulic Conductivity of Unsaturated Porous Media. Water Resour Res, Vol. 12, No. 3, pp. 513-522.

- Naglič, N., Kechavarzi, C., Coulon, F., and Pintar, M., 2014. Numerical Investigation of the Influence of Texture, Surface Drip Emitter Discharge Rate and Initial Soil Moisture Condition on Wetting Pattern Size. Irrig, Sci., DOI 10.1007/s00271-014-0439-z. 
- Ojha, C. S. P., and Rai, A. K.,1996. Nonlinear Root-Water Uptake Model. Journal of Irrigation and Drainage Engineering, Vol. 122, No. 4. ASCE, ISSN 0733- 9437/96/0004 0198-0202.

- Peddinti, S. R., Kambhammettu, B. V. N. P., Lad, R. S., Simunek, J., Gade, R. M., and Adinarayana, J, 2020. A macroscopic soil-water transport model to simulate root water uptake in the presence of water and disease stress." Journal of Hydrology. Vol. 587. DOI: 10.1016/j.jhydrol.2020.124940.0022-1694.

- Prasad, R., 1988. A Linear Root Water Uptake Model". Journal of Hydrology. Vol. 99, PP. 297-306.

- Selim, T., Berndtsson, R., and Persson, M., 2013. Simulation of Soil Water and Salinity Distribution under Surface Drip Irrigation. Civil Engineering Department, Egypt Irrig. and Drain, DOI: 10.1002/ird.1739.

- Shankar, V.; K.S., Hari Prasad; C.S.P. Ojha, M. ASCE; and Raos. Govindaraju, 2012. Model for Nonlinear Root Water Uptake Parameter. Journal of Irrigation and Drainage Engineering, Vol. 138, No. 10, pp. 905-917.

- Van Genuchten, M. Th., 1980. A closed- form Equation for Predicting the Hydraulic Conductivity of Unsaturated Soils. Soil Science Society America Journal, Vol. 44, pp.892898.

- Vogel, T., and M. Císlerová, 1988. On the Reliability of Unsaturated Hydraulic Conductivity Calculated from the Moisture Retention Curve, Transport in Porous Media, 3,1-15,1988.

- Vrugt, J. A., Hopmans, J. W., and Šimůnek J., 2001a. Calibration of a Two-Dimensional o Root Water Uptake Model. Soil Science Society of America Journal, Vol. 65, No. 4, pp. 1027-1037.

- Vrugt, J. A., van Wijk, M. T., Hopmans, J. W., and Šimůnek, J., 2001b. One-, Two-, and Three-Dimensional Root Water Uptake Functions for Transient Modeling.Water Resources Research, Vol. 37, No. 10, pp. 2457-2470.

- Willmott, C. J., 1982. Some comments on the evaluation of model performance. Bulletin of the American Meteorological Society, Vol. 63, No. 11, pp. 1309-1313.

- Yadav, B. K., and Mathur, S., 2008. Modeling Soil Water Uptake by Plants using Nonlinear Dynamic Root Density Distribution Function. Journal of Irrigation and Drainage Engineering. DOI: 10.1061/ (ASCE) 0733-9437. Vol. 134, PP. 430-436.

\section{NOMENCLATURE}

$\mathrm{a}=$ inverse of the air- entry value, $(1 / \mathrm{cm})$;

$\mathrm{H}=$ soil water pressure head, $(\mathrm{cm})$;

$\mathrm{K}(\mathrm{H})=$ unsaturated hydraulic conductivity, $(\mathrm{cm} / \mathrm{hr})$; 
$\mathrm{K}_{\mathrm{s}}=$ saturated hydraulic conductivity, $(\mathrm{cm} / \mathrm{hr})$;

$\mathrm{n}=$ pore size distribution index, dimensionless;

$\mathrm{Q}=$ discharge rate, $\left(\mathrm{cm}^{3} / \mathrm{hr}\right)$;

$\mathrm{r}=$ radial (horizontal) coordinate, $(\mathrm{cm})$;

$\mathrm{S}(\mathrm{H})=$ a sink term that explains the root water uptake expressed as a water volume that removed from a unit volume of soil per unit time, $\left(\mathrm{cm}^{3} \mathrm{~cm}^{-3} / \mathrm{hr}\right)$;

$\mathrm{t}=$ time, $(\mathrm{hr})$;

$\mathrm{z}=$ drip depth, (cm);

$\theta=$ volumetric soil moisture, $\left(\mathrm{cm}^{3} / \mathrm{cm}^{3}\right)$;

$\theta_{\mathrm{i}}=$ initial soil moisture content, $\left(\mathrm{cm}^{3} / \mathrm{cm}^{3}\right)$;

$\theta_{\mathrm{r}}=$ residual soil moisture content, $\left(\mathrm{cm}^{3} / \mathrm{cm}^{3}\right)$

$\theta_{\mathrm{s}}=$ saturated soil moisture content, $\left(\mathrm{cm}^{3} / \mathrm{cm}^{3}\right)$. 